\title{
Australian Journal of

\section{Agronomic performance of creeping peanut (Arachis hypogaea L.), grown in different row spacing and plant densities under conditions of humid subtropical climate}

\author{
Tiago Zoz' ${ }^{1}$, Antonio Carlos Torres da Costa ${ }^{2}$, Fábio Steiner ${ }^{1}$, André Zoz', Travis Wilson Witt ${ }^{3}$, Alan Mario \\ Zuffo $^{1 *}$
}

'State University of Mato Grosso do Sul - UEMS, Agronomy Deartment, MS 306 Road, Km 6, Cassilândia, Mato Grosso do Sul, Brazil

${ }^{2}$ Western Parana State University - Unioeste, Agricultura Science Center, Marechal Cândido Rondon Campus, 1777 Pernambuco Street, Marechal Cândido Rondon, PR, Brazil

${ }^{3}$ USDA-ARS, PA, CSRL, Plant Stress and Germplasm Development Research, Lubbock, TX 79415, USA

\section{*Corresponding author.: alan_zuffo@hotmail.com}

\begin{abstract}
In recent years, peanut (Arachis hypogaea L.) cultivation has increased in the humid subtropical areas of Brazil. However, there is little technical information for its cultivation under these conditions. The objective of this study was to evaluate the agronomic performance of cultivar RUNNER IAC 886, when grown in different row spacing and plant populations. The experiment was a randomized block design in a $2 \times 4$ factorial with two plant densities (seven and ten plants per meter) and four row spacings (0.40, $0.60,0.80,1.00 \mathrm{~m}$ ), with four replications. The grain yield with ten plants per meter was approximately $32.1,16.7,13.7$ and $11.5 \%$ higher than seven plants per meter for the row spacings of $0.40,0.60,0.80$ and $1.00 \mathrm{~m}$, respectively. The highest peanut grain yield was observed in the $0.6 \mathrm{~m}$ row spacing.
\end{abstract}

Keywords: Arachis hypogaea L., plant spatial arrangement, grain yield.

Introduction

Until the early 1970s, peanuts (Arachis hypogaea L.), were one of the most cultivated crops in Brazil. However, since the 1980s some technological and market issues resulted in a significant reduction in the cultivated area in the country (Fachin et al., 2014). Currently, peanut cultivation in Brazil has been used mainly in reform areas of sugarcane or in recovery areas of degraded pastures. According to Santos (2005), about $80 \%$ of the sugarcane reform areas are occupied by peanuts. The use of new cultivars, the adoption of appropriate management practices and mechanization of the whole production process contribute to the increase of crop yield (Dias et al., 2009).

The low yield in the Brazilian state of Parana is because the crop is poorly explored. The main varieties used by producers originated in the state of São Paulo, especially the Runner IAC 886 that is a creeping cultivar widely used in Western Parana (Nakagawa et al., 2000).

According to Nakagawa (1983), the plant's population is one of the main factors that can limit the yield potential of peanuts. Due to this fact the row spacing and population density needs to be explored. Currently, due to convenience, the producers have sowed peanuts with the same machinery and row spacing used for corn $(0.80$ to $0.90 \mathrm{~m})$ with a density of seven plants per meter.

However, higher yields may be observed with different row spacing and planting densities, so it was necessary to perform studies that aim to evaluate the spatial arrangement of this cultivar. The definition of spacing and sowing density is a cultural practice of great importance in planning and managing a crop to improve grain yield in a particular region (Severino et al., 2006, Silva et al., 2006).

In theory, the most appropriate plant arrangement is the one in which the distribution of the plants in the line is more uniform due to the utilization of environmental conditions, allowing the plants a better use of these resources, influencing the pods and grain yield (Peixoto, 2008; Kunz, 2007). Lauer (1994) stated that in equidistantly spaced plants, there is less competition for nutrients, light, and other production factors.

The objective of this study was to evaluate the agronomic performance of creeping peanut (Arachis hypogaea L. cV. RUNNER IAC 886), grown in different row spacing and plant populations in the humid subtropical climate of Parana, Brazil.

Results and Discussion

\section{Row spacing}

The row spacing affected the grain and pod yield of the crop. With a decrease in the row spacing, there was an increase in the plant population that influenced the yield of peanut. 
Table 1. Description of treatments, area evaluated per plant and plant population.

\begin{tabular}{lccc}
\hline Row spacing & Plant density & Area evaluated per plant & Plants ha $^{-1}$ \\
\hline $\mathrm{m}$ & plants $\mathrm{m}^{-1}$ & $\mathrm{~m}^{2}$ & $\mathrm{n}$ o \\
0.40 & 7 & 0.057 & 175000 \\
0.60 & 7 & 0.086 & 116667 \\
0.80 & 7 & 0.114 & 87500 \\
1.00 & 7 & 0.143 & 70000 \\
0.40 & 10 & 0.040 & 250000 \\
0.60 & 10 & 0.060 & 166667 \\
0.80 & 10 & 0.080 & 125000 \\
1.00 & 10 & 0.100 & 100000 \\
\hline
\end{tabular}

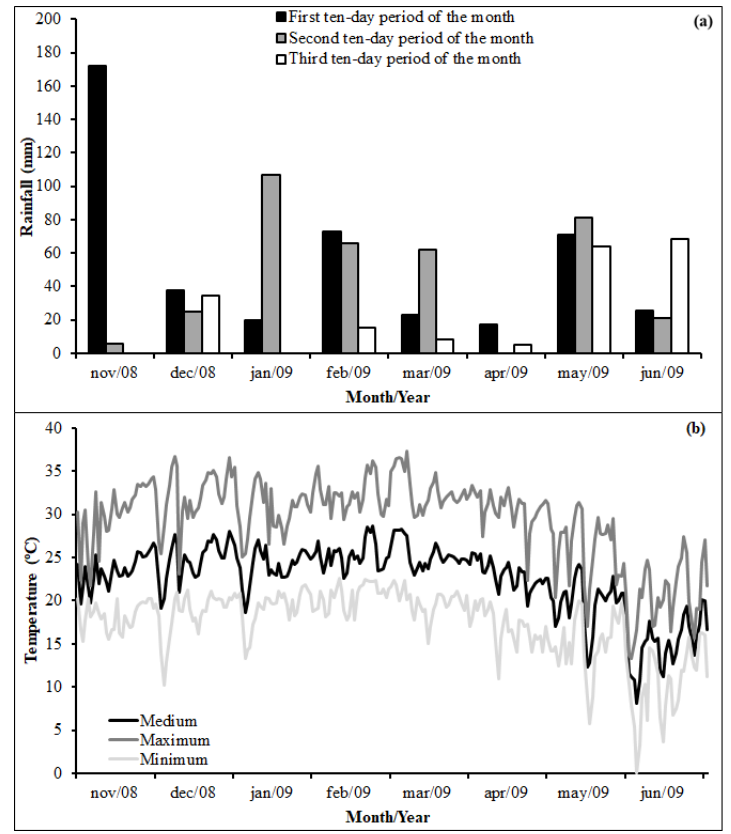

Fig 1. Rainfall (a) and maximum, medium and minimum temperatures (b) during the experiment, Maripá - PR, 2009.

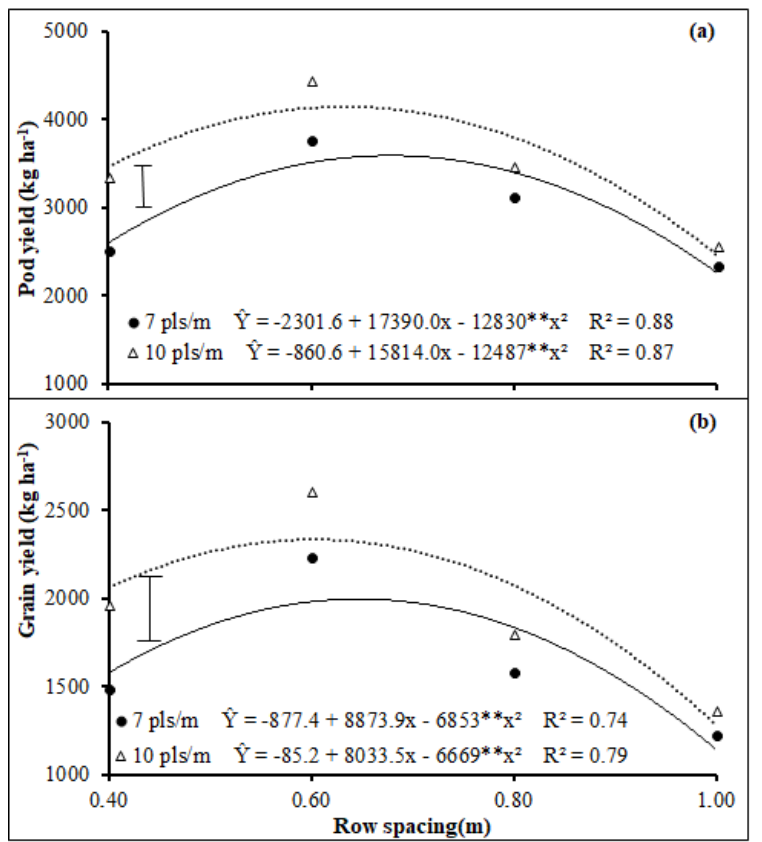

Fig 2. Grain and pod yield of creeping peanut in a plant density of seven and ten plants per meter in different row spacing under conditions of humid subtropical climate. Maripá - PR, 2009. ** Significant at $1 \%$ of probability. Vertical bar represents minimal significant difference (MSD) $(p<0.05)$. 


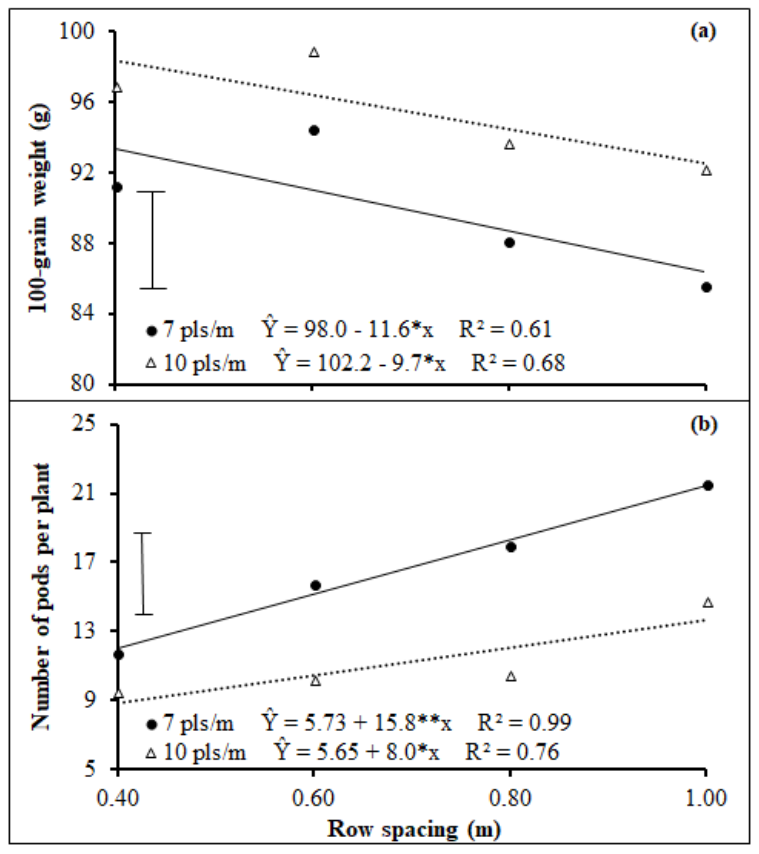

Fig 3. 100-grain weight (a), number of pods per plant (b) of creeping peanut in a plant density of seven and ten plants per meter, in different row spacing under conditions of humid subtropical climate. Maripá $-\mathrm{PR}, 2009$. ${ }^{* *}$ and ${ }^{*}$ significant at $1 \%$ and $5 \%$ of probability, respectively. Vertical bar represents minimal significant difference (MSD) $(p<0.05)$.

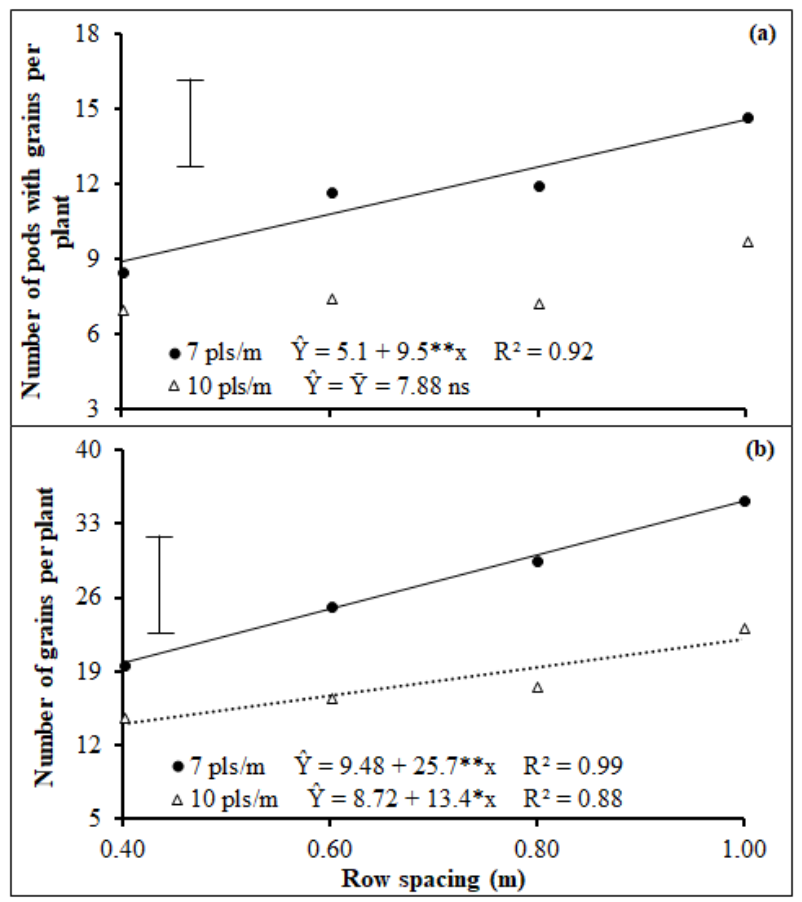

Fig 4. Number of pods with grains per plant (a) and number of grains per plant (b) of creeping peanut in a plant density of seven and ten plants per meter, in different row spacing under conditions of humid subtropical climate. Maripá $-\mathrm{PR}, 2009 .{ }^{* *}$ and ${ }^{*}$ significant at $1 \%$ and $5 \%$ of probability, respectively., ns - not significant. Vertical bar represents minimal significant difference (MSD) $(p<0.05)$.

According to Nakagawa et al. (2000) with an increase in plant population there is an increase in the yield of peanut, but this increase of grain yield occurs until the ideal number of plants per area is reached. After the ideal number of plants per area is exceeded the grain yield decreases.

An increase in a pod and grain yield was observed using the row spacing of up to 0.66 and $0.63 \mathrm{~m}$, respectively (Fig. 2a and $2 \mathrm{~b}$ ). The more narrow row spacing showed a lower peanut yield because of the competition among plants for sunlight, nutrients, water, and shadowing; which reduces the photosynthetic rate andthe productivity. When the row spacing exceeds 0.66 and $0.63 \mathrm{~m}$, the productivity efficiency starts to decrease, because the unexplored area by the plant remained, reducing the productivity per meter.

The smaller row spacing allowed for canopy closure and consequently, less water loss from the soil through evaporation. In part, this increase in yield can be attributed to the better weed control that occurred with the reduction 
in row spacing. The creeping peanut is very susceptible to yield losses, 74 to $95 \%$, due to weed infestation (Dias et al., 2009; Nepomuceno et al., 2007; Agostinho et al., 2006).

Plant densities

Among the population densities, a higher pod and grain yield was observed when ten plants per meter were used. The 100 -grain weight was the only production component that showed higher means in the density of ten plants per meter (Fig. 3a). Thus, it can be inferred that the higher productivity that was achieved with the highest population density is attributed to the higher number of plants per area and the biggest grain weight. In the higher plant density and the narrower row spacing the greater 100-grain weight was observed (Fig. 3a). As seed size increased, a smaller number of pods per plant was observed (Fig. 3b). The pods are considered physiological sinks; therefore, with the increase in the number of sinks, there must be a redistribution of photoassimilates, reducing the amount available per pod.

The largest number of pods per plant was found in the lower plant density and higher row spacing (Fig. 3b). This result can be attributed to the greater branching of the plants as the free space for development increases and the competition for nutrients, water, and light decreases. The cultivar used in this experiment has creeping growth habit by branches, and with the increased space between plants there was an increase in the number of branches and the number of pods. Similar results were observed in peanuts with an erect growth habit (Bellettini and Endo, 2001).

The plant density within the row is a modifying factor of the plant architecture, which favors its adaptation to different conditions (Peixoto et al., 2002). The number of pods per plant is the most affected production component by the plant population and is inversely related to the plant density (Nakagawa et al., 1994). Similar results were observed by Bellettini and Endo, (2001) with peanut of erect growth habit.

The largest number of pods with grains were found in the lower plant density and higher row spacing (Fig. 4a), due to the higher number of pods per plant. The percentage of pods without grains showed no difference between the densities and row spacings. Also, there was no increase in the proportion of pods without grains; however, differences in grain number were observed due to the larger number of pods per plant.

There was no significant difference in the number of grains per pod, probably because this parameter is determined by genetic characteristics of the cultivar. The largest number of grains per plant occurred in the lower plant density and higher row spacing and can be attributed to the greater number of pods per plant obtained under these conditions (Fig. 4b).

\section{Materials and Methods}

\section{Description of the study environments}

The experiment was performed during 2009 in Maripá - PR, at Estância Zoz Farm, located at $24^{\circ} 22$ 'S latitude, $53^{\circ} 44^{\prime}$ W longitude, and altitude of $380 \mathrm{~m}$ in a clayey eutroferric Red Latossol, with a flat and lightly hilly topography (Embrapa, 2013). Before the the experiment, soil samples were collected at $0-20 \mathrm{~cm}$ layers and the chemical analysis showed the following results: $\mathrm{pH}$ in $\mathrm{CaCl}_{2}$ : 5.4; O.M .: $36.23 \mathrm{~g} \mathrm{dm}^{-3} ; \mathrm{P}$ $\left(\right.$ Melich $\left.^{-1}\right): 15.34 \mathrm{mg} \mathrm{dm}^{-3} ; \mathrm{K}\left(\right.$ Melich $\left.^{-1}\right): 1.11 \mathrm{cmol}_{\mathrm{c}} \mathrm{dm}^{-3} ; \mathrm{Ca}$ $(\mathrm{KCl}): 6.39 \mathrm{cmol}_{\mathrm{c}} \mathrm{dm}^{-3} ; \mathrm{Mg}(\mathrm{KCl}): 2.26 \mathrm{cmol}_{\mathrm{c}} \mathrm{dm}^{-3} ; \mathrm{H}+\mathrm{Al}: 5.54$ $\mathrm{cmol}_{\mathrm{c}} \mathrm{dm}^{-3}$; Al: $0.00, \mathrm{cmol}_{\mathrm{c}} \mathrm{dm}^{-3} \mathrm{SB}: 9.76, \mathrm{cmol}_{\mathrm{c}} \mathrm{dm}^{-3}$; CEC: 15.30, $\mathrm{cmol}_{\mathrm{c}} \mathrm{dm}^{-3}$ and $\mathrm{V} \%$ : 64 .

The climate is humid subtropical, Cfa according to the Köppen classification, with an annual rainfall of $1,500 \mathrm{~mm}$ and average annual temperature of $21.4^{\circ} \mathrm{C}$. The rainfall and temperature data during the development of experimental is in Fig. $1 \mathrm{~A}$ and $1 \mathrm{~B}$, respectively.

\section{Experimental design and trial management}

The experiment was performed in a randomized block design with four replications, in a $2 \times 4$ factorial, with two plant densities: seven and ten plants per meter, and four row spacings: $0.40 ; 0.60 ; 0.80$; and 1.00 meter (Table 1). Each experimental unit consisted of $6 \mathrm{~m}$ long with $5 \mathrm{~m}$ wide, and for the evaluations, the two outer rows and $0.5 \mathrm{~m}$ at each end were ignored.

The soil preparation was performed with subsoiling and harrowing. The furrows were manually opened in a row in different predetermined row spacings. The sowing of RUNNER IAC 886, the main cultivar with creeping growth habit grown by producers in Brazil, was performed by hand. Initially, 12 seeds per meter were sown, and after crop establishment, thinning was performed to achieve the plant densities of seven and ten plants per meter.

\section{Evaluations}

When the plants reached the $R_{8}$ stage, plants were uprooted, and the harvest occurred by hand. Ten plants were randomly selected within the plot to make assessments of the number of pods per plant, number of pods with grains per plant, number of grains per pod and number of grains per plant. The difference between the total number of pods per plant and the number of pods with grains per plant was expressed as a percentage of pods without grain. The rest of the plot was threshed, cleaned, weighed and then corrected to $13 \%$ moisture to get the peanut yield in a pod. Subsequently, a pod sample was collected, and the peel was removed to weigh again and determine the yield. The 100grain weight was determined as described by Brasil, 2009.

\section{Statistical Analysis}

Data were analyzed by analysis of variance and the means obtained for the row spacings were adjusted to regression equations, and the means of plants population were compared using the LSD test $(p<0.05)$.

\section{Conclusion}

To get the highest yield of creeping peanut at conditions of humid subtropical climate, it is recommended to sow ten plants per meter with $0.60 \mathrm{~m}$ between rows.

\section{Acknowledgments}

The authors thank the Foundation for Support to the Development of Education, Science and Technology of the State of Mato Grosso do Sul - FUNDECT, by financial support. Mention of trade names or commercial products in this 
article is solely for the purpose of providing specific information and does not imply recommendation or endorsement by the U. S. Department of Agriculture. The U. S. Department of Agriculture is an equal opportunity provider and employer.

\section{References}

Agostinho FH, Gravena R, Alves PLCA, Salgado TP, Mattos ED (2006) The Effect of Cultivar on Critical periods of weed control in peanuts. Peanut Sci. 33(1):29-35.

Brasil (2009) Ministério da Agricultura e Reforma AgráriaRegras para análise de sementes. Brasília, Secretaria Nacional de Defesa Agropecuária.

Bellettini NMT, Endo RM (2001) Comportamento do amendoim "das águas", Arachis hypogaea L., sob diferentes espaçamentos e densidades de semeadura. Acta Sci. Agron., 23(5):1249-1256.

Dias TCS, Alves PLCA, Pavani MCMD, Nepomuceno M (2009) Efeito do espaçamento entre fileiras de amendoim rasteiro na interferência de plantas daninhas na cultura. Planta Daninha, 27(2):221-228.

Embrapa - Empresa Brasileira de Pesquisa Agropecuária (2013) Centro Nacional de Pesquisa de Solos. Sistema Brasileiro de Classificação de Solos. 3 ed. Brasília: Embrapa Solos.

Fachin GM, Junior JBD, Glier CAS, Mrozinski CR, Costa ACT, Guimarães VF (2014) Características agronômicas de seis cultivares de amendoim cultivadas em sistema convencional e de semeadura direta. Rev Bras Eng Agri Ambiente, 18(2):165-172.

Kunz JH, Bergonci JI, Bergamaschi H, Dalmago GA, Heckler BMM, Comiran F (2007) Uso da radiação solar pelo milho sob diferentes preparos do solo, espaçamento e disponibilidade hídrica. Pesqui Agropecu Bras. 42(11):1511-1520.

Lauer J (1994) Should I be planting my corn at a 30-inch row spacing? Wisconsin Crop Manager. 1(6):56-57.

Nakagawa J, Lasca DC, Neves JPS, Neves GS, Sanchez SV, Barbosa V, Silva MN, Rossetto CAV (1994) Efeito da densidade de semeadura na produção de amendoim. Pesqui Agropecu Bras. 29(10):1547-1555.

Nakagawa J, Lasca DC, Neves GS, Neves JPS, Silva MN, Sanchez SV, Barbosa V, Rossetto CA (2000) Densidade de plantas e produção de amendoim. Sci Agric. 57(1):67-73

Nakagawa J, Nojimoto T, Rosolem CA, Almeida AM, Lasca DHC (1983) Efeitos da densidade de semeadura na produção de vagens de amendoim. Científica, 1(11):79-86.

Nepomuceno M, Alves PLCA, Dias TCS, Cardozo NP, Pavani MCMD (2007). Efeito da época de semeadura nas relações de interferência entre uma comunidade infestante e a cultura do amendoim. Planta Daninha, 25(3):481-488.

Peixoto CP, Camara GMS, Martins MC, Marchiori LFS (2002) Efeitos de épocas de semeadura e densidade de plantas sobre a produtividade de cultivares de soja no Estado de São Paulo. Rev Agric. 77:265-291.

Peixoto CP, Gonçalves JÁ, Peixoto MFSP, Carmo DO (2008) Desempenho de cultivares e linhagens de amendoim irrigado. Bragantia, 67:673-684.

Santos CR, Godoy IJ, Fávero PA (2005) Melhoramento do amendoim. In: O Agronegócio do amendoim no Brasil. EMBRAPA.

Severino LS, Coelho DK, Moraes CRA, Gondin TMS, Vale LS (2006) Otimização do espaçamento de plantio para a mamoneira cultivar BRS Nordestina. Rev Ol Fibros, 10(1/2):993-999.

Silva PRF, Sangoi L, Argenta G, Strieder ML (2006) Importância do arranjo de plantas na definição da produtividade do milho. Porto Alegre: UFRGS: Evangraf. 